\title{
Effect of Direct Sowing and Transplanting on Yield Performance of Indian Mustard
}

\author{
Har Vir Singh*, M.K. Meena, R.L. Choudhary, M.L. Dotaniya, \\ M.D. Meena, R.S. Jat, O.P. Premi and P.K. Rai \\ ICAR-Directorate of Rapeseed-Mustard Research, Bharatpur, Rajasthan 321 303, India \\ *Corresponding author
}

\begin{abstract}
A B S T R A C T
Keywords

Direct sowing, Transplanting, Mustard, Yield

Article Info

Accepted:

07 January 2019

Available Online:

10 February 2019

The present investigation was carried-out during 2016-17 and 2017-18 at ICARDirectorate of Rapeseed Mustard Research, Bharatpur, Rajasthan to find out the effect of direct sowing and transplanting on yield of mustard. There were six treatment combinations of two crop establishment techniques (direct seeding of the seed using a seed-drill and establishment of the crop through transplanting) and three dates of sowing i.e. $13^{\text {th }}$ October, 22 October and 01 November during both the years. The results revealed that significantly higher values of most of the growth and yield parameters were observed where transplanting of the seedlings was done on $13^{\text {th }}$ October during both the years. Similarly, the seed yield was increased by $15-20 \%$ under transplanting techniques over direct seeding of the crop. In conclusion, early establishment of the Indian mustard through transplanting technique could be an alternative option to enhance the productivity of the Indian mustard particularly under the late harvesting of kharif crops.

\section{Introduction}

Indian mustard [Brassica juncea (L.) Czern \& Coss.] is playing a major role in oilseed production and satisfying most of the oil requirement of Indian consumers. It is the most important winter season oilseed crop, which thrives best in light to heavy loam soil in areas having $25-40 \mathrm{~cm}$ rainfall. Mustard is cultivated in mostly under temperate climates. It is also grown in certain tropical and subtropical regions as a cold weather crop. Date of transplanting is important in increasing the mustard productivity per unit area. Several reasons responsible for low productivity is non-adoption of good

agronomic practices like optimum date of sowing and planting geometry. Very often the farmers have to sow the crop late due to delayed monsoon rain, and late harvesting of Kharif crops resulting in poor yield. Delay in sowing reduces the yield due to its depressing effect on the plant growth, flowering duration, seed formation and productivity (Bali et al., 2000).Sowing at proper time allows sufficient growth and development of a crop to obtain a satisfactory yield and also provide variable environmental conditions within the same location for growth and development of crop and yield stability (Pandey et al., 1981). If the mustard is sown late, duration is reduced due to the high temperature during the
\end{abstract}


reproductive phase with concomitant reduction in yield (Kumari et al., 2004). In general, it was observed that the mustard crop sown after October $30^{\text {th }}$ resulted in lower yields (Panda et al., 2004). Transplanting the crop rather than normal drilling may be a costlier method of crop establishment, however, the labour requirement for sowing and then thinning the crop twice, to remove extra plants, may be more costlier. Transplanted crop have the exact plant population with mathematical precision, and there is also some time benefit after harvest of the kharif crops. Through transplanting, the full potentiality of individual plants can be realized and yield more than drilling of seeds. However, these points are not yet studied so far scientifically. Hence, the present investigation on "Effect of direct sowing and transplanting on yield performance of Indian mustard" was undertaken to generate the scientific information on feasibility of transplanting as well as the comparison effect of direct sowing and transplanted on yield of Indian mustard. However, late sowing of this crop resulted in yield losses and thus affected the supply-chain of the oil in the market. The forceful late sowing conditions of the crop are mainly because of delayed harvesting of kharif crops. Therefore, early crop establishment through transplanting technique could be a better alternative to minimize the yield losses in mustard. The main aim of this study was to quantify the effect of direct seeding over transplanting to see the yield effect in mustard. Therefore, to address the above issues, a field experiment was conducted at ICAR-Directorate of Rapeseed Mustard Research, Bharatpur, Rajasthan.

\section{Materials and Methods}

The experiment was conducted during 201617 and 2017-18 at research farm, ICARDirectorate of Rapeseed-Mustard Research, Bharatpur located at $77^{\circ} 3^{\prime}$ E longitude, $27^{\circ} 15^{\prime}$
$\mathrm{N}$ latitude and at an altitude of 178.37 meter above mean sea level. The region falls under Agro climatic Zone III a (semi-arid Eastern plain) with sub-tropical and semi-arid climate. The climate of this zone is typically semiarid, characterized with wide range of temperature between summer and winter. High temperature with high wind velocity during summers and low temperature during winters are the characteristic features of climatic condition. The average rainfall of the locality is around $650 \mathrm{~mm}$ of which 85 percent is contributed by south-west monsoon during July to August. Weather parameters play a great role in affecting growth and development process of crops, hence it is important to present climatic variables. The physio-chemical properties of soil are described in table 1 .

The mean weekly meteorological observations recorded at ICAR-Directorate of Rapeseed-Mustard Research, Bharatpur during the crop growth period. The mean weekly maximum and minimum temperature during the crop growing seasons of mustard fluctuated between 18.3 to $40.9^{\circ} \mathrm{C}$ and 3.5 to $22.1^{\circ} \mathrm{C}$. The mean daily evaporation from USWB class a pan evaporimeter ranged from 1.0 to $9.7 \mathrm{~mm}$ per day. The average relative humidity fluctuated between 20.4 to 57.8 percent at noon. The bright sunshine hours varied from 5.9 in January to 9.3 in April. Rainfall received during 2016-17 and 2017-18 was $55.8 \mathrm{~mm}$ and $26.6 \mathrm{~mm}$ (Table 2).

\section{Treatment details and management of field}

There were six treatment combinations of two crop establishment techniques (direct seeding of the seed using a seed-drill and establishment of the crop through transplanting) and three dates of sowing i.e. $13^{\text {th }}$ October, 22 October and 01 November during both the years. Simultaneously, direct seeding was also done on the same day of 
transplanting. Recommended doses of fertilizers i.e. $80 \mathrm{~kg} \mathrm{~N}, 40 \mathrm{~kg} \mathrm{P}_{2} \mathrm{O}_{5}$ and $40 \mathrm{~kg}$ $\mathrm{K}_{2} \mathrm{O} /$ ha were applied uniformly in the experimental field.

Other standard package and practices of raising a good crop were followed. The RH 406 variety is used in this study. Seedlings were raised in root trainers and transplanting of the 8-10 days old seedlings were done in the field. The plants of 2-3 leaves were ready for transplanting and translated in the afternoon during 4-5 pm in pits. After transplanting a light irrigation was given to get established the plants. A buffer nursery was prepared for gap filling of the same variety. Gap filling was taken up after 8 days of transplanting at the spot. To eliminate weeds in all the plots of experimental area, one hoeing was done at 25 days after sowing. One pre sowing irrigation was given and two irrigations were applied to the crop as per treatments. The crop was affected by some aphids during the maturity period of the crop. Therefore, no control measures were required in the mustard crop. The maturity period of all the date of sowing was different. The crop was harvested as soon as 80 per cent silique turn yellowish brown to prevent shattering. Thereafter, plants from each net plot area were harvested carefully, bundled, tagged and were taken to threshing floor and kept separately. After proper sun drying the bundles were threshed separately. Seed yield from each plot was recorded from each plot after thorough cleaning.

\section{Results and Discussion}

\section{Seed yield (q/h)}

Data (Table 3) indicates that transplanting time brought out significant effect on seed yield of mustard. Significantly highest seed yield was produced under 13th October planting. However, planting of mustard on $1^{\text {st }}$ November produced significantly lower seed yield which was lower than $22^{\text {nd }}$ October and 13th October planted crop, respectively. The same trend was also observed in direct sowing of mustard.

Table.1 Physical and chemical properties of soil at the experimental site

\begin{tabular}{|c|c|}
\hline Particulars & Values \\
\hline \multicolumn{2}{|l|}{ Mechanical composition (Bouyoucos 1962) } \\
\hline Sand $(\%)$ & 19.2 \\
\hline Silt $(\%)$ & 51.3 \\
\hline Clay $(\%)$ & 29.4 \\
\hline Texture class & Silty clay loam \\
\hline \multicolumn{2}{|l|}{ Physical properties } \\
\hline Bulk density (g/cm3) (Rana et al., 2014) & 1.52 \\
\hline Field capacity (\% by weight) (Richards, 1954) & 12.50 \\
\hline Permanent wilting point (\%) (Richards 1954) & 2.35 \\
\hline \multicolumn{2}{|l|}{ Chemical properties } \\
\hline Organic carbon (\%) (Walkley and Black 1934) & 0.24 \\
\hline Available N (kg ha $\left.{ }^{-1}\right)($ Subbiah and Asija 1956) & 126.30 \\
\hline Available $\mathbf{P}\left(\mathrm{kg} \mathrm{ha}^{-1}\right)$ (Olsen et al., 1954) & 17.23 \\
\hline Available K (kg ha $\left.{ }^{-1}\right)($ Jackson 1973) & 149.26 \\
\hline pH (1:2 soil water suspension) (Piper 1950) & 8.3 \\
\hline
\end{tabular}


Table.2 The weekly meteorological data during crop growth period (pooled data of two years)

\begin{tabular}{|c|c|c|c|c|c|c|c|c|c|c|c|}
\hline \multirow[b]{2}{*}{ 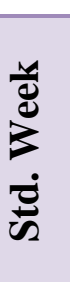 } & \multirow[t]{2}{*}{ Date } & \multicolumn{2}{|c|}{ Temp $\left({ }^{\circ} \mathbf{C}\right)$} & \multicolumn{2}{|c|}{ RH (\%) } & \multirow[b]{2}{*}{ 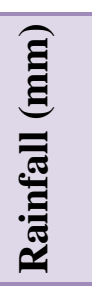 } & \multirow[b]{2}{*}{ 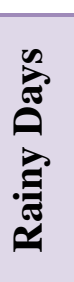 } & \multirow[b]{2}{*}{ 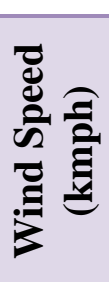 } & \multirow[b]{2}{*}{ 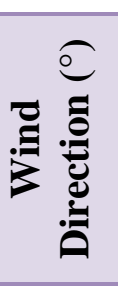 } & \multirow[b]{2}{*}{ 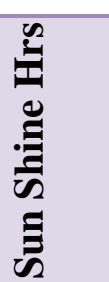 } & \multirow[b]{2}{*}{ 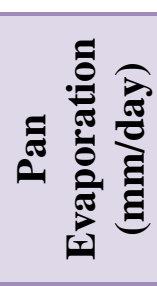 } \\
\hline & & Max & Min. & I & II & & & & & & \\
\hline 40 & $01-07$ & 36.1 & 23.6 & 78.4 & 49.5 & 1.9 & 1 & 4.1 & 202 & 7.8 & 7.4 \\
\hline 41 & $08-14$ & 36.5 & 20.5 & 76.5 & 39.2 & 0.8 & 0 & 3.0 & 240 & 8.3 & 5.3 \\
\hline 42 & $15-21$ & 36.5 & 18.1 & 71.9 & 35.4 & 0.0 & 0 & 2.4 & 254 & 8.6 & 4.6 \\
\hline 43 & $22-28$ & 35.4 & 17.1 & 75.6 & 33.5 & 0.0 & 0 & 2.4 & 235 & 8.4 & 3.9 \\
\hline 44 & $29-04 \mathrm{~N}$ & 31.9 & 15.1 & 82.8 & 40.7 & 0.0 & 0 & 1.6 & 171 & 6.8 & 2.3 \\
\hline 45 & 05-11 & 31.3 & 13.3 & 83.7 & 37.1 & 0.0 & 0 & 1.6 & 253 & 5.0 & 2.1 \\
\hline 46 & $12-18$ & 28.4 & 12.7 & 85.5 & 43.1 & 0.0 & 0 & 2.3 & 200 & 5.5 & 1.8 \\
\hline 47 & $19-25$ & 27.3 & 9.7 & 86.5 & 40.1 & 0.0 & 0 & 2.8 & 257 & 7.5 & 1.6 \\
\hline 48 & $26-02 \mathrm{D}$ & 26.6 & 10.0 & 86.5 & 49.2 & 0.0 & 0 & 2.1 & 237 & 7.8 & 2.1 \\
\hline 49 & 03-09 & 23.0 & 10.1 & 92.0 & 54.2 & 0.0 & 0 & 1.3 & 222 & 4.4 & 1.1 \\
\hline 50 & $10-16$ & 23.0 & 9.4 & 92.8 & 52.7 & 0.0 & 0 & 2.0 & 234 & 5.7 & 1.4 \\
\hline 51 & $17-23$ & 23.6 & 6.5 & 89.8 & 46.7 & 0.0 & 0 & 2.5 & 275 & 6.6 & 1.6 \\
\hline 52 & $24-31$ & 22.4 & 6.9 & 91.0 & 57.4 & 0.0 & 0 & 1.5 & 224 & 6.9 & 1.7 \\
\hline 1 & 01-07J & 18.9 & 7.4 & 95.7 & 71.5 & 0.0 & 0 & 1.1 & 162 & 3.5 & 0.9 \\
\hline 2 & $08-14$ & 20.6 & 3.5 & 92.0 & 46.2 & 2.1 & 1 & 1.5 & 240 & 6.9 & 1.5 \\
\hline 3 & $15-21$ & 22.0 & 4.4 & 92.9 & 47.7 & 0.0 & 0 & 1.7 & 223 & 7.7 & 1.9 \\
\hline 4 & $22-28$ & 21.4 & 8.1 & 93.0 & 62.6 & 17.2 & 1 & 2.0 & 219 & 4.7 & 1.4 \\
\hline 5 & 29-04F & 24.8 & 8.0 & 92.7 & 50.3 & 0.0 & 0 & 1.8 & 257 & 7.9 & 2.5 \\
\hline 6 & $05-11$ & 22.6 & 7.1 & 90.6 & 48.6 & 0.0 & 0 & 2.6 & 250 & 6.4 & 2.0 \\
\hline 7 & $12-18$ & 26.1 & 8.3 & 91.6 & 46.3 & 1.3 & 1 & 3.1 & 263 & 7.6 & 1.8 \\
\hline 8 & $19-25$ & 30.0 & 11.5 & 87.2 & 36.3 & 0.0 & 0 & 2.7 & 255 & 8.8 & 3.5 \\
\hline 9 & $26-04 \mathrm{M}$ & 30.9 & 12.4 & 87.1 & 39.8 & 0.0 & 0 & 3.4 & 230 & 8.0 & 3.8 \\
\hline 10 & $05-11$ & 30.0 & 11.4 & 84.7 & 40.7 & 6.6 & 1 & 4.1 & 243 & 8.1 & 4.1 \\
\hline 11 & $12-18$ & 31.5 & 12.2 & 81.9 & 30.4 & 0.0 & 0 & 3.0 & 249 & 8.0 & 4.4 \\
\hline 12 & $19-25$ & 34.8 & 15.8 & 73.1 & 27.9 & 0.0 & 0 & 3.8 & 271 & 8.4 & 5.8 \\
\hline 13 & $26-01 \mathrm{~A}$ & 39.1 & 18.0 & 61.1 & 19.6 & 0.0 & 0 & 5.5 & 250 & 9.4 & 8.1 \\
\hline 14 & 02-08 & 38.1 & 21.0 & 65.9 & 26.8 & 11.4 & 1 & 5.4 & 186 & 8.5 & 8.4 \\
\hline 15 & 09-15 & 37.3 & 19.8 & 67.1 & 27.0 & 9.6 & 1 & 5.8 & 244 & 9.5 & 7.5 \\
\hline 16 & $16-22$ & 41.5 & 23.8 & 68.2 & 29.2 & 0.0 & 0 & 5.2 & 236 & 9.0 & 10.5 \\
\hline 17 & $23-29$ & 40.1 & 23.8 & 54.2 & 34.4 & 0.4 & 0 & 6.6 & 243 & 9.3 & 11.0 \\
\hline
\end{tabular}


Table.3 Yield influenced by direct sowing and transplanting dates

\begin{tabular}{|l|c|c|c|}
\hline Treatments & \multicolumn{3}{|c|}{ Yield (q/ha) } \\
\hline Direct sowing & $2016-17$ & $2017-18$ & Mean \\
\hline $\mathbf{1 3 ~ O c t ~}\left(\mathbf{D}_{\mathbf{1}}\right)$ & 33.47 & 30.39 & 31.93 \\
\hline $\mathbf{2 2}$ Oct $\left(\mathbf{D}_{\mathbf{2}}\right)$ & 31.39 & 28.14 & 29.77 \\
\hline $\mathbf{1 ~ N o v}\left(\mathbf{D}_{\mathbf{3}}\right)$ & 25.22 & 24.42 & 24.82 \\
\hline $\mathbf{C D}(\mathbf{P}=\mathbf{0 . 0 5})$ & 4.83 & 2.83 & \\
\hline SEm \pm & 1.19 & 0.70 & \\
\hline Date of transplanting & & & 38.80 \\
\hline $\mathbf{1 3 ~ O c t ~}\left(\mathbf{T}_{\mathbf{1}}\right)$ & 40.38 & 37.22 & 35.82 \\
\hline $\mathbf{2 2}$ Oct $\left(\mathbf{T}_{\mathbf{2}}\right)$ & 36.37 & 35.27 & 29.35 \\
\hline $\mathbf{1 ~ N o v}\left(\mathbf{T}_{\mathbf{3}}\right)$ & 29.41 & 29.29 & \\
\hline $\mathbf{C D}(\mathbf{P}=\mathbf{0 . 0 5})$ & 0.49 & 0.11 & \\
\hline SEm $\mathbf{0}$ & 0.12 & 0.02 & \\
\hline
\end{tabular}

Economic yield of crop depends on the source-sink relationship and also on the different components of source and sink. In general, overall impact of treatments on production of biological, seed and stover yield was significant in transplanting of mustard on 13th October over $22^{\text {nd }}$ October and $1^{\text {st }}$ November planted crop. Early transplanting on 13 October produced highest seed yield $(38.8 \mathrm{q} / \mathrm{ha})$ might be due to larger growing period and cumulative effect of effective rainfall and favourable weather conditions which helped in better growth and development of the mustard plants and resulted into better seed yield. However, mustard transplanted on $20^{\text {th }}$ October was found significantly higher. Delayed transplanting decreased the yield attributes and yield as these parameters were adversely influenced in the present experiment as the sowing was delayed beyond October 13. In direct sowing of mustard the maximum yield was observed in $13^{\text {th }}$ October sowing (31.93 $\mathrm{q} / \mathrm{ha})$ followed by $22^{\text {nd }}$ October and $1^{\text {st }}$ November sowing. Rapeseed and mustard when sown later of October faced with cool and even frosty nights as well as reduced sunshine hours which adversely affected photosynthesis and other growth as well as development processes in plants resulting in decreased seed, and biological yields. Adverse effect of low temperature on flowering, siliquae setting and seed development in rapeseed and mustard have also been reported by, Adak et al., 2011, Biswas et al., 2011, Singh and Singh (2002), Sihag et al., (2003), Sharma et al., (2006) and Kumari et al., (2012).

The same trend was also noticed by Sonani $e t$ al., (2002), Panda et al., (2004), and Khushu and Singh (2005) who noted that late sowing caused delayed flowering time, decreased flowering duration and reduced seed yield.

In conclusion, the results revealed that significantly higher values of most of the growth and yield parameters were observed where transplanting of the seedlings was done on $13^{\text {th }}$ October during both the years. Similarly, the seed yield was increased by 15 $20 \%$ under transplanting techniques over direct seeding of the crop. In conclusion, early establishment of the Indian mustard through transplanting technique could be an alternative option to enhance the productivity of the Indian mustard particularly under the late harvesting of kharif crops. 


\section{References}

Adak, T., Bhaskar, N. and Chakravarty, N.V.K. (2011). Response of Brassica to micro environment modification under semi-arid agro ecosystem. Indian Journal of Agriculture Science., 81 (8): 744-50.

Bali, A.S., Shah, M.H., Hasan, B. (2000). Effect of plant density on Brown Sarson (B. campestriss) under different levels of nitrogen and phosphorus. Indian Journal of Agronomy, 45: 174-178.

Biswas, C., Singh, R. and Vijaya, P.K. (2011). Dynamics of white rust disease in mustard (Brassica juncea) in relation to date of sowing and weather parameters. Indian Journal of Agriculture Science 81 (12): 1187-90.

Bouyoucos G J. 1962. Hydrometer method for making particle size analysis of soils. Agronomy Journal 54: 464.

Jackson M L. 1973. Soil Chemical Aanalysis, 2nd Edition, pp 498. Prentice Hall of India Pvt Ltd, New Delhi.

Khan, M. N. and Tak, G.M. (2002). Performance of different date of sowing and spacing. Annals of Agricultural Research, 23 (3): 430436.

Khushu, M. K. and Singh, M. (2005). Thermal response of mustard under rainfed condition of Jammu. Environment and Ecology, 23 (3): 683-686.

Kumari, A., Singh, R.P. and Yeshpal (2012). Productivity, nutrient uptake and economics of mustard hybrid (Brassica juncea) under different planting time and row spacing. Indian Journal of Agronomy, 57 (1): 61-67.

Masood, Mujtaba; Shamsi, Imran H. and Khan, N. (2003).Impact of Row Spacing and Fertilizer Levels (Diammonium Phosphate) on Yield and Yield Components of Canola.Asi. J. Plant Sci., 2: 454-456.

Olsen B C, Cole C V, Watenabe F S and Dean L A. 1954. Estimation of available phosphorus by extraction with sodium carbonate. USDA Circular No. 939, p 19.

Panda, B. B., Bandyopadhyay, S.K. and Shivay, Y.S. (2004). Effect of irrigation level, sowing dates and varieties on growth, yield attributes, yield, consumptive water use and water use efficiency of Indian mustard (Brassica juncea). Indian Journal of Agriculture Science, 74 (6): 331-342.

Panse, V.G. and Sukhatme, P.V. (1967). Statistical methods for Agricultural Workers, ICAR, Publication New Delhi.

Piper C S. 1950. Soil and Plant Analysis, p 286-7. The University of Adelaide, Australia.

Rana K S, Choudhary A K, Sepat S, Bana R S and Das A. 2014. Methodological and Analytical Agronomy, p 276. Post Graduate School, IARI, New Delhi, India.

Richards L A. 1954. Diagnosis and Improvement in Saline, Alkali Soils. Handbook No. 60, USDA, Washington.

Sahar, Keivanrad, Delkhosh, Babak, Hossein, Amir, Rad, Shirani and Zandi, Peiman (2012).The effect of different rates of nitrogen and plant density on qualitative andquantitative traits of Indian mustard.Adv. in Environ. Biol., 6(1): 145-152,

Sharma, S. K., Mendhe, S.N., Kolte, H., Rajput, G.R. and Yenpreddewar, M.D. (2006). Effect of sowings and irrigation management on growth and yield of mustard (Bressica juncea). Journal of Soils and Crop, 16 (4): 455-459.

Sihag, J. S., Manohar, S.S. and Chaudhary, T. 
(2003). Combined effect of sulphur and time of sowing on yield attributes, yield and quality of mustard (Brassica juncea (L.) Czerh and Coss.). Journal of Ecology and Physiology, 6 (1): 65 68.

Singh, G. K. and Prasad, k. (2003).Studies on the effect of row spacing and nitrogen doses on the yield of and profit from Indian mustard.Prog. Agri., 3(1/2): 146-147.

Singh, S. K. and Singh, G. (2002). Response of Indian mustard (Brassica juncea) varieties to nitrogen under varying sowing dates in eastern Uttar Pradesh. Indian Journal of Agronomy., 47 (2):
242-248.

Sonani, V. V., Patel, P.T. and Patel, G.G. (2002). Performance of mustard under different dates of sowing in Bhal and Coastal Agro-climatic zone of Gujarat. Journal of Oilseeds Research., 19 (1): 122.

Subbiah B V and Asija G L. 1956. A rapid procedure for the estimation of available $\mathrm{N}$ in soils. Current Science 25(8): 259-60.

Walkley A J and Black C A. 1934. Estimation of soil organic carbon by the chronic acid titration method. Soil Science 37: 29-38.

\section{How to cite this article:}

Har Vir Singh, M.K. Meena, R.L. Choudhary, M.L. Dotaniya, M.D. Meena, R.S. Jat, O.P. Premi and Rai, P.K. 2019. Effect of Direct Sowing and Transplanting on yield Performance of Indian Mustard. Int.J.Curr.Microbiol.App.Sci. 8(02): 509-515. doi: https://doi.org/10.20546/ijcmas.2019.802.058 